\title{
PENERAPAN SISTEM BAGI HASIL PADA TABUNGAN MUDHARABAH PADA BMT-MMU PASURUAN
}

\author{
Esy Nur Aisyah \\ Fakultas Ekonomi Universitas Islam Negeri (UIN) Maliki Malang \\ Jl. Gajayana No. 50 Malang
}

Abstract

In the case of gathering the society fund through Mudharabah saving, need standards of operational procedure by BMT (inverse) and the members of a cooperative (Inventory) as a frame work seriously to provide a professional human resource. The profit of both of them have to decided before when made agreement. The profit comparative of profit sharing depend on factors influenced the small big of profit sharing. This study is qualitative research by using a descriptive method that supposed to describe the application of profit sharing, and the factors influenced the small big of profit sharing. In addition, it will analyze the application problems and provide the alternative problem solving. To get a data validity on this study, the writer use a qualitative analysis by triangulation as a technical data analysis.

Keywords: profit sharing, tabungan mudharabah

Islam sebagai pedoman hidup manusia, merupakan agama yang tidak hanya berkaitan dengan masalah ritual, akan tetapi merupakan sistem yang komprehensif dan mencakup seluruh aspek kehidupan, termasuk masalah industri keuangan sebagai salah satu motor penggerak roda perekonomian. Ekonomi tidak lepas dari kehidupan manusia, sehingga masalah perekonomian telah diatur dalam al Qur'an dan Hadits. Salah satu contoh dapat dilihat dalam surat al- Qashash juz 28 ayat 77 yang mengatur secara cukup terperinci aturan muamalah diantara manusia. Allah swt. berfirman: 
"Dan carilah pada apa yang telah dianugerahkan Allah kepadamu (kebahagiaan) negeri akhirat, dan janganlah kamu melupakan bahagianmu dari (kenikmatan) duniawi dan berbuat baiklah (kepada orang lain) sebagaimana Allah telah berbuat baik, kepadamu, dan janganlah kamu berbuat kerusakan di (muka) bumi. Sesungguhnya Allah tidak menyukai orang-orang yang berbuat kerusakan." (Al-Qashash:77).

Keberadaan lembaga keuangan mempunyai peranan penting terhadap perkembangan perekonomian suatu Negara. Posisi lembaga keuangan sangat strategis dalam menggerakkan roda perekonomian. Bersamaan dengan fenomena semakin bergairahnya masyarakat untuk kembali ke ajaran agama, banyak bermunculan lembaga ekonomi yang berusaha menerapkan prinsip syari'ah Islam terutama lembaga-lembaga keuangan, seperti perbankan, asuransi, dan Baitul Maal Wat Tamwil (BMT). Khusus mengenai BMT menurut data yang ada, saat ini telah berdiri kurang lebih 3000 BMT di seluruh Indonesia.

Pengembangan BMT juga ditujukan untuk meningkatkan mobilisasi dana masyarakat yang selama ini belum terlayanai oleh sistem keuangan konvensional. Selain itu, sejalan dengan upaya-upaya restrukturisasi perbankan, pengembangan lembaga keuangan syari'ah merupakan suatu alternatif sistem pelayanan jasa keuangan dengan berbagai kelebihan yang dimilikinya.

Sistem bagi hasil adalah karakteristik umum dan landasan dasar bagi operasional lembaga keuangan Islam. Karena dengan sistem bagi hasil, baik instansi maupun perorangan dapat menerapkan prinsip keadilan yang telah dianjurkan dalam agama Islam. Seperti halnya di BMT MMU yang memberikan pelayanan jasa keuangan ekonomi mikro, dalam meningkatkan mobilisasi dana masyarakat, serta penerapan sistem bagi hasil dengan nasabah tabungan maupun pembiayaan.

Berdasarkan hasil wawancara, Prinsip Tabungan yang digunakan oleh BMT MMU adalah akad mudharabah. Produk tabungan Mudharabah yang di tawarkan BMT kepada masyarakat yaitu tabungan umum mudharabah, dan mudharabah berjangka. Dari hasil penelitian terdahulu (Abdul Karim, 2005:98), kesimpulan penelitiannya menyatakan bahwa faktor yang mempengaruhi masyarakat menabung di BMT MMU Sidogiri Pasuruan adalah faktor budaya yang mempunyai dua komponen yaitu faktor agama dan faktor bagi hasil sebagai bentuk penghindaran dari unsur riba.

BMT MMU sebagai mudharib, dalam mendapatkan keuntungan, mereka menyalurkan modal dari nasabah (shahibul maal) kepada masyarakat yang membutuhkan dana melalui berbagai produk pembiayaan. Dan kemudian atas dasar prinsip bagi hasil, BMT sebagai mudharib dari penabung (shohibul maal), harus membagikan keuntungan yang diperolehnya kepada penabung. Dan dalam hal ini juga memerlukan mekanisme perhitungan bagi hasil antara BMT (mudharib) dan Penabung (shahibul maal). 
Berdasarkan permasalahan di atas maka tujuan penelitian ini adalah; pertama, untuk mendeskripsikan penerapan sistem bagi hasil tabungan umum mudharabah dan mudharabah berjangka di BMT MMU Pasuruan.kedua, mendeskripsikan faktor yang mempengaruhi bagi hasil tabungan umum mudharabah dan mudharabah berjangka di BMT MMU Pasuruan.

\section{METODE}

Jenis penelitian ini adalah kualitatif dengan pendekatan deskriptif. Penelitian kualitatif didefinisikan oleh Bogdan \& Taylor (1975:5) dalam Moleong (2006:4) adalah sebagai prosedur penelitian yang menghasilkan data deskriptif berupa katakata tertulis atau lisan dari orang-orang dan perilaku yang dapat diamati. Dalam penelitian ini peneliti mendeskripsikan tentang penerapan sistem bagi hasil, serta faktor-faktor yang mempengaruhi terhadap besar kecilnya bagi hasil di BMT MMU Pasuruan. Dan menurut Supardi (2005 : 28), Penelitian deskripsi secara garis besar merupakan kegiatan penelitian yang hendak membuat gambaran atau mencoba mencandra suatu peristiwa atau gejala secara sistematis, faktual dengan penyusunan yang akurat.

\section{HASIL DAN PEMBAHASAN}

\section{Menabung dalam Perspektif Islam}

Menabung adalah tindakan yang dianjurkan oleh Islam, karena dengan menabung berarti seorang muslim mempersiapkan diri untuk pelaksanaan perencanaan masa yang akan datang, sekaligus untuk menghadapi hal-hal yang tidak diinginkan. Dalam al-qur' an terdapat ayat-ayat yang secara tidak langsung telah memerintahkan kaum muslimin untuk mempersiapkan hari esok lebih baik (Antonio, 2000:205206):

a. Al-Qur'an

"Dan hendaklah takut kepada Allah orang-orang yang seandainya meninggalkan dibelakang mereka anak-anak yang lemah, yang mereka khawatir terhadap (kesejahteraan) mereka. Oleh sebab itu hendaklah mereka bertakwa kepada Allah dan hendaklah mereka mengucapkan perkataan yang benar. (An-nisa':9).

b. Al_Hadits

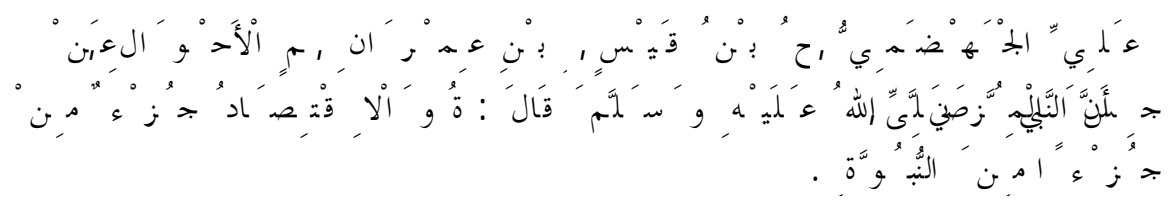


"Tingkah laku yang baik, pelan-pelan dalam mengerjakan sesuatu, dan sederhana adalah sebagian dari dua puluh empat bagian kenabian." (H.R Tarmizy:2.010)

\section{Sistem Bagi Hasil dan Perhitungannya}

Bagi hasil menurut terminology asing (Inggris) dikenal dengan profit sharing. Profit sharing dalam kamus ekonomi diartikan pembagian laba (Muhammad, 2005: 105). Adapun menurut Muhammad (2001) dalam Ridwan (2004: 120), secara istilah profit sharing merupakan distribusi beberapa bagian laba pada para pegawai dari suatu perisahaan. Bentuk-bentuk distribusi ini dapat berupa pembagian laba akhir, bonus prestasi, dll. Dengan demikian, bagi hasil merupakan sistem yang meliputi tatacara pembagian hasil usaha antara pemilik dana dan pengelola dana.

Bagi hasil dalam lembaga keuangan syari'ah adalah bagi hasil keuntungan maupun kerugian. Jadi, jika dalam usaha bersama mengalami resiko maka dalam konsep bagi hasil, kedua belah pihak akan sama-sama menanggung resiko. Shahibul maal (nasabah) akan mengalami kerugian dalam modal, sedangkan pihak pengelola dana akan kerugian dalam tenaga yang telah dikeluarkannya. Dengan permasalahan itu, maka kedua belah pihak dalam konsep bagi hasil adalah adanya partisipasi dalam menanggung resiko.

Muhamad (2000: 47) berpendapat bahwa secara prinsipil bagi hasil dapat diartikan sebagai prinsip muamalat berdasarkan syari'ah dalam melakukan usaha bank seperti dalam hal: (a) Menetapkan imbalan yang akan diberikan masyarakat sehubungan dengan penggunaan atau pemanfaatan dana masyarakat yang dipercayakan. (b) Menetapkan imbalan yang akan diterima sehubungan dengan penyediaan dana kepada masyarakat dalam bentuk pembiayaan baik dalam bentuk investasi maupun modal kerja. (c) Menetapkan imbalan sehubungan dengan kegiatan lain yang dilakukan oleh bank dengan prinsip bagi hasil.

Prinsip bagi hasil merupakan karakteristik umum dan landasan dasar bagi operasional bank Islam secara kesuluruhan, di mana bank Islam berdasarkan kaidah mudharabah dengan menjadikan bank sebagai mitra bagi nasabah ataupun bagi pengusaha yang meminjam dana (Antonio, 2001: 137). Secara umum prinsip bagi hasil dalam perbankan syari' ah dapat dilakukan dalam empat akad utama yaitu: almusyarakah, al-mudharabah, al-muzaro'ah, dan al-musyaqah. Muhammad (2005:117-120), juga menjelaskan tentang poin-poin yang diperhitungkan dalam proses perhitungan bagi hasil. Adapun poin-poin tersebut adalah sebagi berikut:

\section{Saldo Rata-Rata Harian}

Langkah-langkah untuk menghitung saldo rata-rata harian adalah sebagai berikut: (1) Menentukan tanggal berapa keuntungan yang diperoleh dari penempatan 
dana akan dibagihasilkan. (2) Jumlah hari yang dihitung dalam satu bulan adalah sesuai dengan hitungan kalender. Dalam pembagian hasil, BMT mempunyai standar nominal tabungan untuk setiap anggota, yaitu minimal mempunyai tabungan sebesar Rp50.000. Dan untuk dibawah standar tersebut anggota tidak mendapatkan bagi hasil disetiap bulannya. Pembagian hasil yang diberikan oleh BMT MMU sebagai mudharib (pengelola modal) dilakukan dengan melalui proses perhitungan bagi hasil. Hal ini juga tidak lepas dengan posisi BMT yang juga sebagai shahibul maal (pemilik modal) dalam menyalurkan dana melalui produk pembiayaan.

Dalam perhitungan bagi hasil, langka-langkah awal BMT MMU dalam penentuan bagi hasil adalah:

1) Penetapan nisbah bagi hasil untuk tabungan mudharabah:

Tabel 1. Nibah Tabungan Mudharabah

\begin{tabular}{cc}
\hline \multicolumn{1}{c}{ Tabungan Mudharabah } & Nisbah $(\boldsymbol{\%})$ \\
\hline 1. Tabungan Umum Mudharabah & $50: 50$ \\
2. Tabungan mudharabah berjangka & \\
- 3 bulan & $52: 48$ \\
- 6 bulan & $55: 45$ \\
- 9 bulan & $57: 43$ \\
- 12 bulan & $60: 40$ \\
\hline
\end{tabular}

Sumber: Laporan Keuangan BMT MMU

2) Menghitung saldo rata-rata tabungan masing-masing anggota. Adapun contoh perhitungannya adalah seperti dibawah ini: Ibu Aisyah mempunyai rekening di BMT MMU. Catatan tabungannya di kartu menunjukkan transaksi sebagai berikut:

Tabel 2. Contoh Bentuk Buku Tabungan IbuAisyah

\begin{tabular}{|c|c|c|c|c|c|}
\hline No/tgl & Snd & Debet $\mathbf{R p}$ & Kredit & Saldo & Val \\
\hline $1 / 01 / 12$ & & & 1.000 .000 & 1.000 .000 & \\
\hline $5 / 01 / 12$ & & & 1.000 .000 & 2.000 .000 & \\
\hline $11 / 01 / 12$ & & & 1.000 .000 & 3.000 .000 & \\
\hline $21 / 01 / 12$ & & & 1.000 .000 & 4.000 .000 & \\
\hline
\end{tabular}

Sumber: Data diolah dari laporan keuangan BMT MMU

Dalam mencari saldo rata-rata tabungan harian adalah sebagai berikut:

\begin{tabular}{|c|c|c|}
\hline 12 & 4 hari $x 1.000 .000$ & 4.000 .000 \\
\hline 12 & 6 hari $x 2.000 .000$ & .000 \\
\hline 12 & $=10$ hari $\times 3.000 .000$ & $=30.0$ \\
\hline 年 & $=11$ hari $x 4.000 .000$ & $=44.000 .000$ \\
\hline mlah & 31 hari & $=90.000 .000$ \\
\hline
\end{tabular}


Sehingga saldo rata-rata harian $=90.000 .000: 31$ hari

$$
=2.903 .225,8
$$

3) Menghitung total saldo rata-rata tabungan anggota

4) Menghitung jumlah pendapatan BMT. Pendapatan BMT Diperoleh dari keuntungan produk pembiayaan, laba provisi/administrasi, dan pendapatan lainlain. Dan perhitungan pendapatan menggunakan pendekatan profit sharing yaitu pendapatan yang dibagikan kepada anggota adalah pendapatan bersih yang sudah dikurangi dengan biaya-biaya operasional.

Dengan mengetahui hasil akhir dari 3 langkah-langkah di atas, maka proses perhitungan bagi hasil di BMT MMU adalah rumus perhitungan bagi hasil adalah:

Bagi Hasil $=\frac{\text { Keuntungan } \times \text { nisbah } \times \text { saldo rata }- \text { rata tabungan anggota }}{\text { Total Saldo Rata }- \text { rata Tabungan Harian }}$

Dalam penentuan perolehan bagi hasil tabungan mudharabah, BMT MMU tidak membatasi jumlah hari dalam menginvestasikan dana dari anggota. Namun BMT hanya memberi standar minimal jumlah saldo tabungan anggota yaitu sebesar RP 50.000. Dengan demikian, Meskipun anggota/nasabah bertransaksi pada akhir bulan dengan minimal saldo tabungan Rp 50.000, mereka akan langsung mendapatkan bagi hasil pada akhir bulan pendistribusian pendapatan. Namun perolehan besarnya bagi hasil disesuaikan dengan jangka waktu transaksi (saldo rata-rata tabungan).

Dari hasil wawancara dengan staf manager, BMT memberikan standar maksimal terhadap prosentase bagi hasil tabungan yaitu 0,070\%. Kemudian kebijakan yng biasanya dilakukan oleh Akunting dalam penentuan besar kecilnya bagi hasil adalah, pertama penyisihan piutang. Penyisihan ini pengkatagorian aktiva yang lancar, cukup lancar dan tidak lancar, di BMT hanya mengambil $0.35 \%$ bagi debet (pembiayaan) dibandingkan dengan ketetapan PPAP (Penyusutan dan Penyisihan Aktiva Produktif) di perbankan. Sehingga dalam hal ini BMT hanya mengambil sedikit pembebanan resiko macet terhadap nasabah.

Kedua, karena BMT hanya membebani PPAP lebih kecil dibandingkan ketetapan PPAP di perbankan, maka kebijakan selanjutnya adalah kelebihan bagi hasil yang ada di atas standar maksimal BMT MMU, dibebankan pada biaya-biaya operasional BMT. Ketiga, dana dialokasikan pada dana ZIS dan dana sosial ke pondok pesantren Sidogiri.

\section{Faktor-Faktor yang Mempengaruhi Besar Kecilnya Bagi Hasil}

Kontrak mudharabah adalah suatu kontrak yang dilakukan oleh minimal dua pihak. tujuan utama kontrak ini adalah memperoleh hasil investasi. Besar kecilnya hasil investasi dipengaruhi oleh banyak faktor. Faktor pengaruh tersebut ada yang berdampak langsung dan ada yang tidak langsung. Dalam faktor langsung, investment rate merupakan prosentase actual dana yang diinvestasikan dari total dana. 
Di BMT MMU dalam perhitungan prosentase bagi hasi juga mempertimbangkan jangka waktu transaksi tabungan. Semakin lama uang ditabung di BMT dapat memperbesar saldo rata-rata tabungan tiap-tiap anggota/nasabah. Jumlah dana yang tersedia untuk diinvestasikan merupakan jumlah dana dari berbagai sumber dana yang tersedia untuk diinvestasikan. Dana tersebut dapat dihitung dengan menggunakan salah satu metode:

- Rata-rata saldo minimum bulanan

- Rata-rata total saldo harian

Investment rate dikalikan dengan jumlah dana yang tersedia untuk diinvestasikan akan menghasilkan jumlah dana aktual yang digunakan. Sedangkan untuk ketentuan nisbah (profit sharing ratio) adalah: (1) Salah satu ciri al mudharabah adalah nisbah yang harus ditentukan dan disetujui pada awal perjanjian. (2) Nisbah antara satu bank dengan bank lainnya dapat berbeda. (3) Nisbah juga dapat berbeda dari waktu ke waktu dalam satu bank, misalnya deposito 1 bulan, 3 bulan, 6 bulan, dan 12 bulan. (4) Nisbah juga dapat berbeda antara satu account dengan account lainnya sesuai dengan besarnya dana jatuh temponya.

Nisbah untuk tabungan umum mudharabah kurang mempengaruhi terhadap prosentase bagi hasil, karena nisbah antara BMT dengan anggota adalah sama yaitu 50:50. Akan tetapi untuk tabungan mudharabah berjangka sangat berpengaruh, karena terdapat perbedaan prosentase antara tiap-tiap jangka waktu deposito misalnya deposito 1 bulan, 3 bulan, 6 bulan, 9 bulan dan 12 bulan.

Sedangkan terkait faktor tidak langsung, dalam penentuan butir-butir pendapatan dan biaya mudharabah dinyatakan bahwa: (1) Bank dan nasabah melakukan share dalam pendapatan dan biaya pendapatan yang dibagi hasilkan merupakan pendapatan yang diterima dikurangi biaya-biaya. (2) Jika semua biaya ditanggung bank, maka hal ini disebut revenue sharing. Prinsip bagi hasil yang dipakai oleh BMT MMU adalah prinsip profit sharing. Sehingga pandapatan/keuntungan yang dibagikan kepada anggota adalah pendapatan yang sudah dikurangi dengan biaya-biaya operasional. Pendapatan BMT MMU adalah keuntungan dari produk pembiayaan, pendapatan provisi/administrasi dan pendapatan lain-lain. (3) Kebijakan akunting (prinsip dan metode akuntansi). Bagi hasil secara tidak langsung dipengaruhi oleh berjalannya aktivitas yang diterapkan, terutama sehubungan dengan pengakuan pendapatan dan biaya (Muhammad, 2005:110-111). Penentuan besar kecilnya bagi hasil di BMT, secara tidak langsung juga dipengaruhi oleh berjalannya aktivitas yang diterapkan BMT MMU secara keseluruhan.

\section{KESIMPULAN DAN SARAN}

\section{Kesimpulan}

Sistem bagi hasil yang diterapkan BMT MMU pada tabungan mudharabah dan mudharabah berjangka adalah mengacu pada prinsip profit sharing. Kemudian 
dalam Penetapan pembagian nisbah bagi hasil, tidak ada kesepakatan antara Nasabah (shahibul maal) dengan BMT (mudharib). Akan tetapi nisbah ditetapkan oleh BMT MMU. Adapun rumus perhitungan bagi hasil adalah sebagai berikut:

Bagi Hasil $=\frac{\text { Keuntungan } \times \text { nisbah } \times \text { saldo rata }- \text { rata tabungan anggota }}{\text { Total Saldo Rata }- \text { rata Tabungan Harian }}$

Rumus perhitungan bagi hasil di atas, dapat digunakan untuk menghitung bagi hasil tabungan umum mudharabah dan mudharabah berjangka. Namun yang membedakan hanyalah dalam penentuan nisbah bagi hasil. Dengan rumus perhitungan bagi hasil di BMT MMU, maka dapat terlihat bahwa faktor-faktor yang mempengaruhi besar kecilnya bagi hasil adalah: (1) Faktor langsung, yaitu Jumlah dana yang tersedia untuk diinvestasikan/didepositokan dan besarnya nisbah bagi hasil. (2)Faktor tidak langsung, yaitu jumlah pendapatan dan kebijakan akunting di BMT MMU Pasuruan.

\section{Saran}

BMT MMU perlu Melakukan sosialisasi produk-produk BMT kepada masyarakat, khususnya produk tabungan mudharabah, dengan melibatkan tokoh masyarakat seperti ulama (kyai) dan ustadz, para dosen dan guru dalam upaya pemahaman masyarakat tentang produk-produk syari'ah. Kemudian melengkapi peralatanperalatan operasional dengan teknologi yang canggih dan modern. Sehingga mampu memberikan pelayanan yang cepat dan memuaskan bagi para nasabah, baik nasabah penabung maupun nasabah pembiayaan.

\section{DAFTAR PUSTAKA}

Antonio, S. 2000, Bank Syari'ah Suatu Pengenalan Umum, Edisi Khusus. Jakarta: Penerbit Aneka Tazkia.

Bakhri, S. 2004. Kebangkitan Ekonomi Syariah di Pesantren Belajar dari Pengalaman Sidogiri, Edisi Pertama. Pasuruan: Penerbit Cipta Pustaka Utama.

Karim, A. 2005. Analisis Faktor-faktor Yang Mempengaruhi Nasabah Menabung Di BMT $M M U-S i d o g i r i$, Skripsi. Tidak dipublikasikan. Fakultas Ekonomi, Universitas Islam Negeri Malang.

Moleong, L. 2006. Metodologi Penelitian Kualitatif, Edisi Revisi. Bandung: Penerbit PT Remaja Rosdakarya.

Muhamad. 2000. Lembaga-lembaga Keuangan Umat Kontemporer, Edisi Pertama. Yogyakarta: Penerbit UII Press.

Muhammad. 2005. Manajemen Bank Syari'ah, Edisi Revisi. Yogyakarta: Penerbit Unit Penerbit dan Percetakan (UPP) AMPYKPN.

Ridwan, M. 2004. Manajemen Baitul Maal Wa Tamwil, Edisi Pertama. Yogyakarta: Penerbit UII Press. 
Supardi. 2005. Metodologi Penelitian Ekonomi dan Bisnis, Edisi Pertama. Yogyakarta: Penerbit UII Press.

El-Dinar, Vol. 1, No 1, Januari 2013 